\title{
Evaluation of Tomato Lines Derived from Landraces of "Tomate Platense" and a Commercial Hybrid in La Plata, Argentina
}

\author{
Lisandro Entio and María de la Merced Mujica \\ School of Agrarian and Forest Science, National University of La Plata, La Plata, Buenos Aires, PC 1900, Argentina
}

\begin{abstract}
In the city of La Plata (Argentina) and the surroundings, there are tomato landraces, widely known as "tomate platense" and particularly prized because of their flavor. The objective was to evaluate seven promissory lines of "tomate platense" (TL) derived from local varieties and a commercial hybrid $(\mathrm{CH})$ considering yield, fruit characters and their possible associations. Nine plants per treatment were arranged in a randomized complete block design $(r=4)$. The following parameters were determined: diameter $(\mathrm{cm})$, height $(\mathrm{cm})$, diameter/height $(\mathrm{D} / \mathrm{H})$ ratio, weight per fruit $(\mathrm{g})$, number of locules, the average number of fruits per plant, the average weight of fruits per plant ( $\mathrm{kg} / \mathrm{plant})$, the yield (ton/ha) and the survival percentage. ANOVA, Tukey's test and Pearson correlation coefficient were applied. The TL showed greater $(P \leq 0.01)$ diameter, $\mathrm{D} / \mathrm{H}$ ratio and number of locules than $\mathrm{CH}$. In all materials, both diameter and height were associated $(P \leq 0.05)$ with the weight per fruit. Six of TL had greater $(P \leq 0.01)$ weight per fruit than HC. Respect to number of fruits per plant, weight of fruits per plant and yield, there were no significant differences among the materials. The survival for $\mathrm{CH}$ was lower $(P \leq 0.05)$ than that for $\mathrm{TL}$. Although fruits with a smaller size and less flattened have been selected, the lines show enough similarity in these characters that identified their common origin. With the fruits smaller and more uniform, and having no joined fruits, these lines may be of interest to be cultivated under low-input system conditions and practical for low-income producers.
\end{abstract}

Key words: Tomato landraces, tomate platense, selected lines, fruit characters, yield components, low-input systems.

\section{Introduction}

Although the goals of the tomato breeding programs vary widely, most of them have undergone four phases: breeding for yield, for post-harvest life, for taste and for nutritional quality in the 70's, 80 's, 90's and currently, respectively [1].

Tomato (Solanum lycopersicum) is native to South America (the Andean region of Chile, Ecuador, Colombia and Peru) and its domestication started there. In the 16th century, it was brought to Europe, where the process continued on a much more intensive level [2]. As a result, at the end of the 19th century, there were already many traditional or local varieties (also called "landraces") with different shapes and colours particularly prized because of their flavor [1].

Corresponding author: María de la Merced Mujica, professor, research field: plant breeding.
According to Harlan [3], landraces are cultures in which plant population has evolved over time to adapt to the local climatic conditions, management, pest and diseases.

In the city of La Plata and the surroundings, there are tomato landraces, widely known as "tomate platense" (TL). These landraces had their origin in materials introduced by European immigrants during the first half of the 20th century, and they were cultivated over time by local horticulturists [4]. Consequently, the materials adapted to the agroclimatic conditions and cultural practices [3]. During the second half of the 20th century, these landraces were improved in yield and commercial suitability with the hybrids varieties. As a consequence, they were displaced from the market, and just a few horticulturists kept them as a tradition for self-consumption [4]. 
Currently, consumers have shown an increased interest on these materials because of its flavor [5]. Besides, there is a marked rise in the prices of hybrids varieties seeds [1]. Then, the obtaining of new varieties with commercial suitability and a good adaptation, starting from these landraces, would be a valid option for low-input systems. Some considered traits for fresh tomato are number, weight, color and shape of the fruit, yield per plant and per hectare, and resistance to biotic factors [6-13]. A breeding program was developed during five years from local tomato varieties with the aim of improved yield and other traits related to commercial suitability. Thus, a set of promising lines was obtained. The considered characters were the smaller and homogenous fruits, absence of joined fruits, phytosanitary behavior and the yield.

Thus, this work was conducted to evaluate seven promissory lines derived from local varieties and a commercial hybrid considering yield, fruit characters and their possible associations.

\section{Materials and Methods}

After a five-year selection of tomato landraces from La Plata, Buenos Aires province, Argentina, seven promissory lines from "tomate platense" (TL) and a commercial hybrid $(\mathrm{CH})$ were evaluated. The study was conducted at the Experimental Farm of Gorina, Ministry of Agriculture of Buenos Aires province, which was located at $34^{\circ} 54^{\prime} 29^{\prime \prime} \mathrm{S}$ and $58^{\circ} 02^{\prime} 25^{\prime \prime} \mathrm{W}$, during the growth cycle 2014-2015.

The materials were seeded in September 2014 in seedlings in a greenhouse. In October 2014, they were transplanted to another greenhouse with a randomized complete block design $(r=4)$. Daily drip irrigation according to water needs, and weekly basic fertilization by means of fertirrigation were applied (300 g of Magnum 44 (13-40-13), $500 \mathrm{~g}$ of magnesium sulphate, $700 \mathrm{~g}$ of potassium nitrate, $400 \mathrm{~g}$ of calcium nitrate and $150 \mathrm{~g}$ of phosphoric acid in $1,000 \mathrm{~L}$ of water). At harvest time, out of five randomly chosen fruits in each experimental unit, the following parameters were determined: diameter $(\mathrm{cm})$, height $(\mathrm{cm})$, diameter/height $(\mathrm{D} / \mathrm{H})$ ratio, weight $(\mathrm{g})$ and number of locules. Also, the average number of fruits per plant and the average weight of fruits per plant (kg/plant) were calculated, as well as the yield (ton/ha) was estimated. Besides, the percentage of survival was calculated. ANOVA and Tukey's test were applied in order to analyze differences among the treatments, and Pearson correlation coefficient to study the correlations among characters of fruits.

\section{Results and Discussion}

\subsection{Fruit Morphological Characters}

The results of the fruit morphological characters analysis showed that the TL presented greater $(P \leq$ 0.01) diameter than $\mathrm{CH}$, and that there were no significant differences among TL. As regards of the height, the TL were lower $(P \leq 0.01)$ than the $\mathrm{CH}$, except for TL2, TL3 and TL7 which did not present significant differences with the $\mathrm{CH}$. The $\mathrm{D} / \mathrm{H}$ ratio was similar among the TL, but all of them had greater $(P \leq 0.01) \mathrm{D} / \mathrm{H}$ ratio than the $\mathrm{CH}$, as a consequence of the more flattened shape of their fruits. All the TL presented a greater $(P \leq 0.01)$ number of locules than the $\mathrm{CH}$ (Table 1).

Some of these traits were also studied by Bruna-Lavilla et al. [9] in 31 "tomate rosa de Barbastro" local varieties and two commercial varieties, and also informed the greater $\mathrm{D} / \mathrm{H}$ ratio for local varieties, although they did not show the diameter and height values. In comparative studies carried out with hybrids originated from local populations and commercial hybrids, Farooq et al. [14] found larger diameter and smaller height in the local materials than that in the commercial hybrids, while Troung et al. [7] did not find significant differences in diameter and height between both materials. In another comparative study, but among seven commercial hybrids, Hernández-Leal et al. [8] did not report significant differences in diameter and height among them. 
Table 1 Fruit morphological characters in seven promissory lines derived from landraces of "tomate platense” (TL) and a commercial hybrid (CH).

\begin{tabular}{lllll}
\hline Material & Diameter $(\mathrm{cm})$ & Height $(\mathrm{cm})$ & D/H ratio & Number of locules \\
\hline TL1 & $7.53^{\mathrm{a}}$ & $4.86^{\mathrm{b}}$ & $1.55^{\mathrm{a}}$ & $2.20^{\mathrm{ab}}$ \\
TL2 & $7.65^{\mathrm{a}}$ & $5.03^{\mathrm{ab}}$ & $1.52^{\mathrm{a}}$ & $2.00^{\mathrm{ab}}$ \\
TL3 & $7.64^{\mathrm{a}}$ & $5.04^{\mathrm{ab}}$ & $1.51^{\mathrm{a}}$ & $1.90^{\mathrm{ab}}$ \\
TL4 & $4.91^{\mathrm{b}}$ & $1.63^{\mathrm{a}}$ & $2.40^{\mathrm{a}}$ \\
TL5 & $8.01^{\mathrm{a}}$ & $4.84^{\mathrm{b}}$ & $1.63^{\mathrm{a}}$ & $1.95^{\mathrm{a}}$ \\
TL6 & $7.92^{\mathrm{a}}$ & $4.89^{\mathrm{b}}$ & $1.63^{\mathrm{a}}$ & $2.00^{\mathrm{ab}}$ \\
TL7 & $7.96^{\mathrm{a}}$ & $4.95^{\mathrm{ab}}$ & $1.52^{\mathrm{a}}$ & $1.75^{\mathrm{b}}$ \\
CH & $7.54^{\mathrm{a}}$ & $5.31^{\mathrm{a}}$ & $1.19^{\mathrm{b}}$ & $1.00^{\mathrm{c}}$ \\
\hline
\end{tabular}

Different letters within each column indicate significant differences by Tukey's test $(P \leq 0.01)$.

From the correlation analysis among the characters, it was observed that in all materials, both diameter and height were associated $(P \leq 0.05)$ with the average weight per fruit. The Pearson correlations coefficient (r) varied between 0.76 and 0.97 for diameter vs. average weight per fruit, and between 0.44 and 0.97 for height vs. average weight per fruit.

These results partially match with those of Estrada-Labrada et al. [10], who reported that only the diameter was associated with the average weight per fruit. Also, it was observed that only in LT5, the average weight per fruit was associated $(P \leq 0.05 ; r=$ 0.68 ) with the $\mathrm{D} / \mathrm{H}$ ratio, showing high uniformity in the independence of these two characters among the materials. In other comparative studies between landraces of "tomate platense" and a commercial hybrid at the beginning of this breeding program, it was informed about a larger variability among the materials for that association [12, 13]. In this sense, these authors report that the association between weight per fruit and the shape varied from the independence to a close relation $(P \leq 0.05)$. This could be explained by the fact that among the breeding program objectives, it was searched to obtain lighter and less flattened fruits $(\mathrm{D} / \mathrm{H}$ ratio close to 1$)$. Meanwhile, Bruna-Lavilla et al. [9], in a study with 31 local varieties of "tomate de Barbastro" and two commercial hybrids, using the $\mathrm{H} / \mathrm{D}$ ratio as an indicator for shape, found a significant and negative association for these traits, which indicated that the heavier fruits were more flattened.
From the correlation outlook, the $\mathrm{CH}$ showed high $r$ values for all characters. This pattern of correlation among the studied characters is variable in TL, having $r$ values as high as those of $\mathrm{CH}$, while other TL (TL3, TL5, TL6) have lower $r$ values, indicating a lower degree of association among the characters.

Those TLs showing a close association among characters are suggested to be considered in future selections for the application of indirect selection.

\subsection{Yield and Yield Components}

All the evaluated TL had a greater $(P \leq 0.01)$ weight per fruit than the $\mathrm{CH}$, except for TL1, which did not present significant differences. Comparing the weight per fruit among TL, there were significant differences $(P \leq 0.01)$ only between TL4 (189.35 g) and TL1 (152.85 g). With respect to number of fruits per plant, yield per plant and yield per hectare, there were no significant differences among the materials (Table 2). In reference to the survival, there were no significant differences among TL (range 94.4\% to $100 \%)$. The $\mathrm{CH}$ survival $(75 \%)$ was lower $(P \leq 0.05)$ than that of TL1, TL3, TL5 and TL6 (Table 3). The yield of $\mathrm{CH}$ was not superior to the TL, contrary to the expected result, because $\mathrm{CH}$ has a high potential yield based on the exploitation of the heterosis. This could be attributed to the effect of the low-input cultural practices, which could have been less favorable for the $\mathrm{CH}$.

These results partially match with that of Bruna-Lavilla et al. [9], who reported that 30 of 31 local 
Table 2 Yield components of seven promissory lines derived from landraces of “tomate platense” (TL) and a commercial hybrid (CH).

\begin{tabular}{lllll}
\hline Material & $\begin{array}{l}\text { Average weight } \\
\text { per fruit }(\mathrm{g})^{* *}\end{array}$ & $\begin{array}{l}\text { Number of fruits } \\
\text { per plant* }\end{array}$ & $\begin{array}{l}\text { Yield per plant } \\
\text { (kg/plant)* }\end{array}$ & $\begin{array}{l}\text { Yield per hectare } \\
\text { (ton/ha)* }\end{array}$ \\
\hline TL1 & $152.85^{\mathrm{bc}}$ & $12.28^{\mathrm{a}}$ & $1.65^{\mathrm{a}}$ & $26.57^{\mathrm{a}}$ \\
TL2 & $167.60^{\mathrm{ab}}$ & $13.71^{\mathrm{a}}$ & $1.71^{\mathrm{a}}$ & $28.04^{\mathrm{a}}$ \\
TL3 & $166.80^{\mathrm{ab}}$ & $9.77^{\mathrm{a}}$ & $1.42^{\mathrm{a}}$ & $23.78^{\mathrm{a}}$ \\
TL4 & $189.35^{\mathrm{a}}$ & $9.14^{\mathrm{a}}$ & $1.61^{\mathrm{a}}$ & $25.33^{\mathrm{a}}$ \\
TL5 & $11.33^{\mathrm{a}}$ & $1.61^{\mathrm{a}}$ & $26.96^{\mathrm{a}}$ \\
TL6 & $181.85^{\mathrm{ab}}$ & $10.16^{\mathrm{a}}$ & $1.68^{\mathrm{a}}$ & $28.15^{\mathrm{a}}$ \\
TL7 & $185.20^{\mathrm{ab}}$ & $11.89^{\mathrm{a}}$ & $1.43^{\mathrm{a}}$ & $23.44^{\mathrm{a}}$ \\
CH & $160.00^{\mathrm{ab}}$ & $9.71^{\mathrm{a}}$ & $1.37^{\mathrm{a}}$ & $18.14^{\mathrm{a}}$ \\
\hline
\end{tabular}

Different letters within each column indicate significant differences by Tukey's test (* $P \leq 0.05 ; * * P \leq 0.01)$.

Table 3 Survival percentage of plants at the end of the harvest time in seven promissory lines derived from landraces of "tomate platense" (TL) and a commercial hybrid (CH).

\begin{tabular}{ll}
\hline Material & Survival (\%) \\
\hline TL1 & $97.22^{\mathrm{a}}$ \\
TL2 & $94.44^{\mathrm{ab}}$ \\
TL3 & $100.00^{\mathrm{a}}$ \\
TL4 & $94.44^{\mathrm{ab}}$ \\
TL5 & $100.00^{\mathrm{a}}$ \\
TL6 & $100.00^{\mathrm{a}}$ \\
TL7 & $94.44^{\mathrm{ab}}$ \\
CH & $75.00^{\mathrm{b}}$ \\
\hline
\end{tabular}

Different letters indicate significant differences by Tukey's test $(P \leq 0.5)$.

varieties of tomato "rosa de Barbastro" were improved in weight per fruit to the two commercial hybrids used as check. While Ullé [15] also showed, in another comparative study among landraces of "tomate platense" and varieties registered by Instituto Nacional de Tecnología Agropecuaria (INTA), that landraces had greater weigh per fruit; however, only some of them presented a higher yield per hectare. Farooq et al. [14] studied 17 experimental hybrids developed from local materials and one commercial variety as a control and found that the commercial variety presented a greater number of fruits per plant, while four of the experimental hybrids was improved to the control in weight per fruit and that two of them resulted similar to the control in yield per plant (kg/plant) and per hectare (ton/ha). Troung et al. [7] also compared four experimental hybrids with two commercial hybrids, and found that the commercial hybrids were greater in weight per fruit, and there were no significant differences in the number of fruits per plant, however the experimental materials were not improved in yield (ton/ha) as comparison to the best commercial hybrid.

\section{Conclusions}

After five years of breeding, the evaluated promissory lines of "tomate platense" showed uniformity in fruit and yield traits. Although fruits with a smaller size and less flattened have been selected, the lines show enough similarity in these characters that identified their common origin.

As expected, this low-input system, applied in this study, was detrimental to the expression of the hybrid variety potential. With the fruits smaller and more uniform, and having no joined fruits, these TL lines may be of interest to be cultivated under low input system conditions and practical for low-income producers.

Thus, both the diffusion and incorporation of these improved old materials as a non-conventional alternative and appropriate to broaden the diversity of the production systems are suggested for consideration.

\section{References}

[1] Bai, Y., and Lindhout, P. 2007. "Domestication and Breeding of Tomatoes: What Have We Gained and What 

and a Commercial Hybrid in La Plata, Argentina

Can We Gain in the Future?" Annals of Botany 100 (5): 1085-94.

[2] Sims, W. L. 1980. "History of Tomato Production for Industry around the World." Acta Horticulturae 100: 25-6.

[3] Harlan, J. R. 1992. Crops and Man, 2nd ed.. Madison, Wisconsin: American Society of Agronomy and Crop Science Society of America, 284.

[4] Garat, J. 2002. "The 'Platense' Tomato in La Plata, Argentina.” Revista Biodiversidad 34: 19-21. (in Spanish)

[5] Proyecto Regional FAO TCP/RLA/3211. 2011. "Food Quality Related to the Origin and Traditions in Latin America." The 2nd Training Seminar-Workshop Report on Geographical Indications and Designations of Origin: Theoretical Framework and Tools for Its Implementation, Presentation of Cases under Construction. Accessed September 22, 2016. http://www.fao.org/fileadmin/ templates/olq/documents/Argentina/8casotomateplatense. pdf. (in Spanish)

[6] Riglos, M., Entio, L. J., Mujica, M. M., and Mezquiriz, N. 2015. "Variability in Yield and Fruit Characters in Tomato 'Platense' Advanced Lines." Revista Biocell 39 (5): 9-10.

[7] Truong, H. T. H., Phan, T. T., and Le, K. T. 2015. "Evaluation on Agronomical Characteristics of F1 Hybrid Tomato Lines in Spring-Summer Season 2015 in ThuaThien Hue." Journal of Agricultural Science and Technology A and B \& Hue University Journal of Science 5: 501-7.

[8] Hernández-Leal, E., Lobato-Ortiz, R., García-Zavala, J. J., Reyes-López, D., Mendez-López, A., Bonilla-Barrientos, O., and Hernández-Bautista, A. 2013. "Agronomic Behavior in Populations F2 of Tomato Hybrids (Solanum lycopersicum L.)." Revista Fitotécnica Mexicana 36 (3): 209-15. (in Spanish)

[9] Bruna-Lavilla, P., Mallor-Giménez, C., and Llamazares-Ortega, A. 2012. "Barbastro Pink Tomato: Characterization of Plant Material." European
Agricultural Fund for Rural Development (EAFRD) and Department of Agriculture, Livestock and Environment, Government of Aragon Technical Information No. 234. Accessed September 29, 2016. http://www.aragon.es/estaticos/GobiernoAragon/Departa mentos/AgriculturaGanaderiaMedioAmbiente/Agricultur aGanaderia/Areas/07_Formacion_Inovacion_Sector_Agr ario/02_Centro_Transferencia_Agroalimentaria/Publicaci ones_Centro_Transferencia_Agroalimentaria/IT_2012/IT 234-12.pdf. (in Spanish)

[10] Estrada-Labrada, Y., Lescay-Batista, E., Vázquez-Ramírez, Y., and Celeiro-Rodríguez, F. 2012. "Genetic Variability and Phenotypic Correlations in Tomato Germplasm (Solanum lycopersicum L.).” Revista Granma Ciencia 16 (2): 8. (in Spanish)

[11] Pérez-Rivas, M. B., Albarracín, M., Moratinos, H., and Zapata-Navas, F. 2012. "Yield and Fruit Quality in Four Cultivars of Tomato (Solanum lycopersicum L.) under Protected Conditions." Revista Facultad Agronomía 29: 395-412. (in Spanish)

[12] Casalla, H., Entio, L. J., Mezkiriz, N., and Mujica, M. M. 2011. "Variability in Weight and Shape of Fruit in Landraces of 'Tomate Platense' and a Commercial Hybrid.” Horticultura Argentina 30 (73): 43. (in Spanish)

[13] Entio, L. J., Mezkiriz, N., Casalla, H., and Mujica, M. M. 2011. "Comparison of Fruit Characters between Landraces of 'Tomate Platense' and a Commercial Hybrid.” Horticultura Argentina 30 (73): 43. (in Spanish)

[14] Farooq, M., Ullah, H., Nawab, N. N., and Qureshi, K. M. 2013. "Evaluation of Indigenous Tomato Hybrids under Plastic Tunnel." Pakistan Journal of Agricultural Research 26 (2): 97-103.

[15] Ullé, J. A. 2007. "Comparison of Tomato Local Varieties Conserved in Situ in Greater La Plata with Registered Varieties by INTA on the National Register of Cultivars." In Proceedings of the 47th Brazilian Congress of Horticulture and IV Brazilian Symposium of Cucurbitaceas. 